\title{
Energized Endocytosis in Human Erythrocyte Ghosts
}

\author{
Stanley L. Schrier, Klaus G. Bensch, Muriel Johnson, and \\ IRENE JUNGA \\ From the Department of Medicine, Stanford University School of Medicine, \\ Stanford, California 94305
}

\begin{abstract}
A B STRACT The mechanism of endocytosis in resealed human erythrocyte ghosts was studied. The energy for endocytosis or micropinocytosis appears to be derived from $\mathrm{Mg}-\mathrm{ATP}$, and membrane internalization is preceded by activation of a membrane-associated $\mathrm{Ca}$,$\mathrm{Mg}$-ATPase and by the active efflux of $\mathrm{Ca}$. Endocytosis, $\mathrm{Ca}, \mathrm{Mg}$-ATPase activity, and active $\mathrm{Ca}$ efflux all require the presence of $\mathrm{Mg}$. Furthermore, these three phenomena, endocytosis, $\mathrm{Ca}, \mathrm{Mg}$-ATPase activity, and active $\mathrm{Ca}$ extrusion, all have a concentration dependence on $\mathrm{Ca}$ such that low concentrations stimulate and higher concentrations inhibit the phenomena. The optimal concentration of $\mathrm{Ca}$ is identical for endocytosis, active $\mathrm{Ca}$ efflux, and $\mathrm{Ca}, \mathrm{Mg}$-ATPase. Morphologic studies indicated that while active $\mathrm{Ca}$ efflux and activation of the $\mathrm{Ca}, \mathrm{Mg}$-ATPase activity occurred promptly upon onset of incubation, there was a significant time delay before endocytosis occurred, which suggests that endocytosis additionally involved a more slowly functioning mechanicochemical mechanism. Ruthenium red, a specific inhibitor of $\mathrm{Ca}, \mathrm{Mg}$-ATPase and $\mathrm{Ca}$ transport, inhibited endocytosis in a concentration-related manner. Prostaglandins $E_{1}$ and $E_{2}$ had no measurable effect on ghost endocytosis, active $\mathrm{Ca}$ efflux, or $\mathrm{Ca}, \mathrm{Mg}$-ATPase activity.
\end{abstract}

\section{INTRODUCTION}

The phenomenon of endocytosis or membrane internalization occurs in a variety of cell types and may be related to phagocytosis or to mechanisms wherein macromolecules or particulates may enter the cell through its otherwise impenetrable plasma membrane $(1,2)$. Human erythrocytes are not usually thought of in the context of phagocytosis or pinocytosis; however, in certain circumstances endocytosis can be seen in circulating human erythrocytes (3-5). A variety of agents (6) can induce membrane internalization in vitro in in-

Received for publication 10 May 1974 and in revised form 12 March 1975. tact human erythrocytes and the extent of endocytosis correlates directly with cellular youth and with the energy metabolism of the red cell, as represented particularly by its ATP content (7).

Endocytosis in human erythrocyte ghosts, as distinguished from intact erythrocytes, was studied by Penniston and Green as a model system for studying energization of plasma membranes by ATP (8). Subsequent studies have indicated that the specific substrate for endocytosis in resealed human erythrocyte ghosts is Mg-ATP (7), and that ADP can substitute partially but other nucleotide di- and triphosphates as well as cAMP function poorly in this regard (9). In addition to a strict requirement for $\mathrm{Mg}$, it was observed that low concentrations of $\mathrm{Ca}$ stimulated erythrocyte (9) ghost endocytosis, whereas higher concentrations of $\mathrm{Ca}$ inhibited endocytosis. This biphasic response to calcium occurred within a concentration range of $0.1-2.0 \mathrm{mM}$. Other forms of endocytosis in erythrocyte ghosts have been described, some of which appear to depend on the ionic strength of the medium and not on any sort of bioenergetic considerations (10). This membrane endovesiculation without requirement of ATP may be related to or entirely distinct from energized endocytosis.

Because energized endocytosis in human erythrocyte ghosts as studied by at least two laboratories $(8,9)$ requires the specific interaction of $\mathrm{Mg}$ and $\mathrm{ATP}$, we studied the interaction of $\mathrm{Ca}, \mathrm{Mg}$, and ATP in erythrocyte ghost endocytosis as a means of investigating a general phenomenon that appears to encompass an energy-linked sequence of events involving plasma membrane invagination followed by closure and resealing of the vacuole mouth, thereby leading to pinocytosis with membrane internalization.

Experiments were designed to compare the concentrations of $\mathrm{Ca}$, ATP, and $\mathrm{Mg}$ that produced optimal activation and then inhibition of the membrane-associated $\mathrm{Ca}, \mathrm{Mg}$-ATPase $(11,12)$ and the related $\mathrm{Ca}$ efflux pump (12-15) with the concentrations of the reactants that 
produced activation and inhibition of ghost endocytosis (9). Attempts were made to study the time relationship between activation of the $\mathrm{Ca}, \mathrm{Mg}$-ATPase and $\mathrm{Ca}$ efflux from ghosts with the onset of morphologically identifiable ghost endocytosis. We also studied the effect of a known inhibitor of membrane-associated $\mathrm{Ca}, \mathrm{Mg}$-ATPase (16) on the phenomenon of ghost endocytosis.

\section{METHODS}

Materials. Materials were obtained from sources previously described (7). $\left[{ }^{32} \mathrm{P}\right] \mathrm{ATP}$ labeled in the $\gamma$ position $\left(\left[\gamma^{32} \mathrm{P}\right] \mathrm{ATP}\right)$ was made as previously described (17). The specific activity achieved was approximately $13-34 \mu \mathrm{Ci} / \mu \mathrm{mol}$. $\left[{ }^{45} \mathrm{Ca}\right] \mathrm{CaCl}_{2}$ was purchased from New England Nuclear (Boston, Mass.) and had a specific activity of $17.5 \mathrm{mCi} / \mathrm{mg}$. Practical grade ruthenium red was obtained from Sigma Chemical Co. (St. Louis, Mo.) and purified, assayed, and standardized according to the method of Luft (18). Prostaglandins $E_{1}$ and $E_{2}$ were provided by Dr. P. Kury and Dr. Harden McConnell, Department of Chemistry, Stanford University.

Resealed erythrocyte ghosts. Fresh heparinized blood from normal human donors was used. The erythrocytes were washed three times with a solution consisting of $154 \mathrm{mM}$ $\mathrm{NaCl}$, with $2 \mathrm{mg}$ glucose $/ \mathrm{ml}$, buffered to $\mathrm{pH} 7.4$ with $5 \mathrm{mM}$ imidazole-glycylglycine. The procedure used in making resealed ghosts was basically that previously described $(7,9)$; however, no $\mathrm{NaF}$ was used in these experiments to avoid interference with energy-dependent processes. Since the events we were following occurred rapidly, equilibration and resealing periods for preparing resealed ghosts were necessarily shorter than those previously used. Hemolysis was carried out at $22^{\circ} \mathrm{C}$ and resealing at $37^{\circ} \mathrm{C}$. Since our primary

\section{EVALUATION OF ENDOCYTOSIS, ERYTHROCYTE SIZE} ATPase ACTIVITY AND $\mathrm{Ca}^{++}$CONTENT IN RESEALED GHOSTS

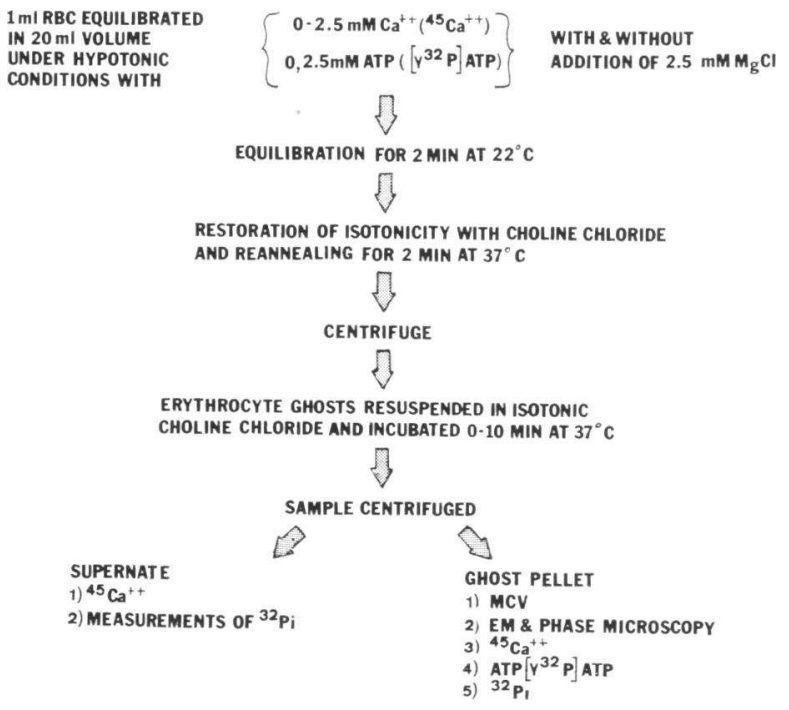

Figure 1 The flow chart indicates the procedures followed in hemolyzing and resealing erythrocyte ghosts, incubating the ghosts, and then analyzing the ghost pellet and suspending medium.
TABLE I

Conditions for Resealing Erythrocyte Ghosts when $2.5 \mathrm{mM}$ ATP Is Present in the Hemolysis Solution

\begin{tabular}{|c|c|c|c|}
\hline \multicolumn{2}{|c|}{$\begin{array}{l}\text { Addition to hemolysis } \\
\text { solution }\end{array}$} & \multirow{2}{*}{$\begin{array}{l}\text { Content of addition in } \\
\text { resealed ghosts }\end{array}$} & \multirow[b]{2}{*}{ ATP leak* } \\
\hline $\mathrm{Ca}$ & $\mathbf{M g}$ & & \\
\hline$m M$ & $m M$ & $\mu \mathrm{mol} / \mathrm{ml}$ packed ghosts & $\%$ \\
\hline
\end{tabular}

A. Resealing of $\mathrm{NaCl}$ tested by addition of $2.0 \mathrm{mM}$ $\left[{ }^{22} \mathrm{Na}\right] \mathrm{NaCl}$ to the hemolysis solution

$\begin{array}{lll}0 & 2.5 & 0.78 \\ 0.1 & 2.5 & 1.35 \\ 0.2 & 2.5 & 1.85\end{array}$

B. Resealing of ATP tested by addition of $2.5 \mathrm{mM}\left[{ }^{32} \mathrm{P}\right] \mathrm{ATP}$ to the hemolysis solution

$\begin{array}{llcc}0 & 0.5 & 0.83 & 15 \\ 0 & 2.5 & 1.23 & 11 \\ 0 & 0 & 0.83,0.87 & 11,18 \\ 0.05 & 0 & 0.83 & 12 \\ 0.10 & 0 & 1.13 & 3 \\ 0.75 & 0 & 1.91 & 0\end{array}$

C. Resealing of $\mathrm{Ca}$ tested by addition of ${ }^{45} \mathrm{Ca}$ in the concentrations indicated to the hemolysis solution

$\begin{array}{lllc}0.25 & 2.5 & 0.005 & 0.08 \\ 0.50 & 2.5 & 0.105 & 0.30 \\ 0.75 & 2.5 & 0.38 & 0.57,0.49 \\ 0.75 & 0 & 0.53 & 0.58,0.66 \\ 1.0 & 2.5 & 0.61 & 0.94,0.90 \\ 5.0 & 2.5 & 2.90 & 5.2\end{array}$

* ATP leak to supernatant medium during the 10-min incubation at $37^{\circ} \mathrm{C}$, expressed as a percentage of the ATP present in ghosts at the beginning of the incubation.

interest was in ghost endocytosis, an ATP-requiring phenomenon in our experiments (9), ATP was always added to the hemolysis solution at a concentration of $2.5 \mathrm{mM}$. Usually $\mathrm{Mg}$ was added at a concentration of $2.5 \mathrm{mM}$, except where its concentration requirement was under study. Fig. 1 indicates the methods used for hemolyzing, resealing, incubating, and analyzing the preparation. It should be emphasized that in working with the three reactants $\mathrm{Ca}, \mathrm{Mg}$, and ATP, there is a special difficulty (12), because when a given concentration of one of these three interacting materials is chosen to explore a specific phenomenon, the optimal concentration of the other two is altered in a complex manner. For example if the concentration of $\mathrm{Ca}$ were altered, there would be a family of curves describing the optimal concentrations for $\mathrm{Mg}$ and $\mathrm{ATP}$ for each new $\mathrm{Ca}$ concentration. Since it appeared that endocytosis in resealed ghosts (9) was optimal when $1.0 \mathrm{mM} \mathrm{Ca}, 2.5 \mathrm{mM} \mathrm{Mg}$, and $2.5 \mathrm{mM}$ ATP were added to the hemolyzing solution, these concentrations served as the basis for concentration variations of $\mathrm{Mg}$ and $\mathrm{Ca}$. In a prior study we had observed that optimal resealing of $\mathrm{NAD}^{+}$and $\mathrm{ADP}$ within ghosts occurred when $0.5 \mathrm{mM}$ $\mathrm{Ca}$ and $2.0 \mathrm{mM} \mathrm{Mg}$ were added during hemolysis reversal (19) at $4^{\circ} \mathrm{C}$. Subsequently, Bodemann and Passow (20) defined the conditions for optimal ghost resealing and they routinely used $4 \mathrm{mM} \mathrm{Mg}$. Complexing agents like ATP had a deleterous effect on resealing (20) at room temperature and 
$37^{\circ} \mathrm{C}$ and the authors speculated that such agents removed the divalent cations, $\mathrm{Ca}$ and $\mathrm{Mg}$, which participated in the maintenance of membrane impermeability. Since $\mathbf{M g}$ addition was used to initiate endocytosis, it was necessary to add the other divalent cation, $\mathrm{Ca}$, to the hemolyzing solution to produce ghosts that would remain relatively impermeable to $\mathrm{Ca}$ and ATP during the course of the experiment. The effectiveness of $\mathrm{Ca}$ and $\mathrm{Mg}$ in producing sealed ghosts in the presence of ATP is shown in Table I, where the ghosts were resealed as indicated in Fig. 1, in the presence of 2.5 $\mathrm{mM}$ ATP and varying concentrations of $\mathrm{Ca}$ and $\mathrm{Mg}$. The effectiveness of resealing was tested with three dissimilar materials: $\mathrm{NaCl}, \mathrm{Ca}$, and ATP. Increasing the concentration of $\mathrm{Ca}$ in the hemolyzing solution increased the effectiveness of resealing of $\mathrm{Na}, \mathrm{ATP}$ and $\mathrm{Ca}$ within ghosts. (Table I.) The very high effectiveness of ${ }^{45} \mathrm{Ca}$ resealing suggested that perhaps some $\mathrm{Ca}$ had been bound to the ghost interior or its contents. The leak of $\left[{ }^{32} \mathrm{P}\right] \mathrm{ATP}$ from resealed ghosts was less than $2 \%$ over a 10 -min period at $37^{\circ} \mathrm{C}$ when optimal concentrations of $\mathrm{Ca}$ were used. The ability of $\mathrm{Ca}$ to improve the resealing of erythrocyte ghosts has been previously observed $(21,22)$.

After the resealing step, the suspension was centrifuged at $15,000 \mathrm{~g}$ at $4^{\circ} \mathrm{C}$ for a total time of $3.5 \mathrm{~min}$; the supernate was discarded. Then $15 \mathrm{vol}$ of isotonic choline chloride, cooled to $4^{\circ} \mathrm{C}$ and buffered to $\mathrm{pH} 7.4$ with $5 \mathrm{mM}$ imidazoleglycylglycine buffer, was added, and the sample was mixed and centrifuged as before. The supernate was again discarded and the sedimented ghosts were brought to volume with buffered isotonic choline chloride for the incubation (Fig. 1). The time elapsed from the end of the resealing step to the beginning of the incubation was $8 \mathrm{~min}$ at temperature of $4^{\circ} \mathrm{C} .1 \mathrm{ml}$ of packed ghosts contained approximately $10^{10}$ ghosts.

No attempt was made to classify the ghosts according to their degree of "leakiness" (20), but since almost all experiments were designed so that $\left[{ }^{32} \mathrm{P}\right] \mathrm{ATP}$ was resealed within ghosts, the extent of ATP leak could be conveniently followed by measuring the appearance of $\left[{ }^{22} \mathrm{P}\right] \mathrm{ATP}$ in the supernatant media during the course of the incubation. In more than 50 experiments the leak of [ $\left.{ }^{22} \mathrm{P}\right] \mathrm{ATP}$ during the course of the incubation was always less than $2 \%$ of the total $\left[{ }^{32} \mathrm{P}\right]$ ATP resealed within ghosts as determined at the start of the incubation.

If $\mathrm{Mg}$ was omitted from the hemolyzing solution, endocytosis, as measured by the radioisotopic method (7) or phase and electron microscopy $(7,9)$, did not occur. Therefore, the addition of $\mathrm{Mg}$ was used to activate endocytosis.

Measurement of ATPase. To measure ATPase activity within erythrocyte ghosts, the resealed ATP was labeled with $\left[\gamma^{22} \mathrm{P}\right] \mathrm{ATP}$. The degradation of ATP as measured by production of inorganic phosphate $\left({ }^{32} \mathrm{Pi}\right)$ and the disappearance of $\left[\gamma^{32} \mathrm{P}\right] \mathrm{ATP}$, both measured by the isobutanolbenzene method, provided a double method for assaying ATPase (17). ATPase activity was expressed as micromoles or nanomoles of ${ }^{32} \mathrm{Pi}$ generated or $\left[\gamma^{32} \mathrm{P}\right] \mathrm{ATP}$ consumed per minute per $10^{10}$ ghosts at $37^{\circ} \mathrm{C}$. This form of expression of activity was used rather than the more usual expression of micromoles ATP per minute per milligram of membrane protein (17). The latter expression is accurate with "white" ghosts, where the amount of membrane protein is generally constant at approximately $7 \mathrm{mg} / \mathrm{ml}$ of packed erythrocyte ghosts. However, in the current study red ghosts were used, and minor variations in conditions produced enough changes in hemoglobin content of membranes so that the number of ghosts was more useful as a denominator than membrane protein content. All experi- ments were performed with two samples of erythrocyte ghosts, one being resealed with $\mathrm{Ca}$ and ATP, and the other containing $\mathrm{Mg}$ in addition to identical concentrations of $\mathrm{Ca}$ and ATP. The difference in ATP degradation between the two samples was taken to represent $\mathrm{Ca}, \mathrm{Mg}$-ATPase activity. Since it was not possible for us to reseal erythrocyte ghosts in the presence of EDTA or EGTA because of the requirements for $\mathrm{Ca}$ and $\mathrm{Mg}$ in resealing the ghosts used in this study, it was not possible to rid the ghost suspension of either $\mathrm{Mg}$ or $\mathrm{Ca}$ (23). Therefore ghosts resealed in the absence of added $\mathrm{Mg}$ have residual $\mathrm{Mg}$ and a small but measurable amount of both $\mathrm{Ca}, \mathrm{Mg}-\mathrm{ATP}$ ase and $\mathrm{Mg}$ ATPase activity. Thus the use of the difference in ATP degradation occurring in ghosts prepared with and without $\mathrm{Mg}$ addition probably underestimates $\mathrm{Ca}, \mathrm{Mg}-\mathrm{ATPase}$. For similar reasons, $\mathrm{Ca}$ efflux is also probably underestimated.

To minimize activation of the Na,K-ATPase, the ghosts were resealed with isotonic choline chloride and all subsequent incubations were carried out at $37^{\circ} \mathrm{C}$ in isotonic choline chloride buffered to $\mathrm{pH} 7.4$ with $5 \mathrm{mM}$ imidazole glycylglycine. The measured $\mathrm{Na}$ concentration of the resealing solution was $4.0 \mathrm{mM}$, while the $\mathrm{K}$ concentration was 2.85 $\mathrm{mM}$. The ghost wash solution as well as the suspending medium during the incubation phase had a $\mathrm{Na}$ content of $1.0 \mathrm{mM}$ or less, and a $\mathrm{K}$ content $0.2 \mathrm{mM}$ or less. After resuspension in the incubating medium, the $\mathrm{Na}$ content within ghosts was $3.0 \mu \mathrm{mol} / \mathrm{ml}$ packed ghosts while the $\mathrm{K}$ content was $0.9 \mu \mathrm{mol} / \mathrm{ml}$ packed ghosts.

Because the $\mathrm{Ca}, \mathrm{Mg}$-ATPase reaction begins as soon as hemolysis starts, thereby exposing the membrane-associated enzyme to the reactants, it was necessary to correct for the $\left[{ }^{32} \mathrm{P}\right]$ ATP degradation and ${ }^{32} \mathrm{Pi}$ generation that had occurred during the $12 \mathrm{~min}$ of hemolysis, resealing, and washing of ghosts. Accordingly in all experiments a "zero time" sample was prepared so that it contained the same amounts of reactants and ghosts as the other flasks but was not incubated at $37^{\circ} \mathrm{C}$, and instead was immediately subjected to centrifugation and separation and analysis (Fig. 1 ). In assaying optimal $\mathrm{Ca}, \mathrm{Mg}-\mathrm{ATPase}$ activity, samples were taken after $0,3,7$, and $10 \mathrm{~min}$ of incubation at $37^{\circ} \mathrm{C}$ and the activity was linear up to $10 \mathrm{~min}$ if the later values were corrected for the zero value. In recording $\mathrm{Ca}, \mathrm{Mg}$ ATPase activity in this study, the values obtained over the first 3-5 $\mathrm{min}$ of incubation were used.

Calcium flux measurements. For most of these experiments, radioisotopic ${ }^{45} \mathrm{Ca}$ was used. The small amount of residual hemoglobin in the resealed ghosts did not cause quenching when the samples were dissolved in Aquasol and the radioisotopic activity was determined by liquid scintillation spectrometry. Sufficient ${ }^{4} \mathrm{Ca}$ was added to adjust the specific activity of $\mathrm{Ca}$ in the hemolyzing solution to approximately $10^{\circ} \mathrm{cpm} / \mu \mathrm{mol}$. Since these experiments were performed with ghosts prepared by hemolyzing erythrocytes by the addition of $20 \mathrm{vol}$ of hypotonic solutions, the residual hemoglobin was $5-10 \%$ of the initial value. In performing flux studies with intact erythrocytes, one generally corrects for cell water, which accounts for approximately $68 \%$ of the erythrocytes' volume, but in the case of these resealed ghosts, where approximately $90-95 \%$ of the volume is cell water, no correction for cell water content of ghosts was made. As noted above under ATPase measurements, in each experiment a zero sample was used as the basis upon which to calculate $\mathrm{Ca}$ efflux. Ca efflux, depending on the $\mathrm{Ca}$ concentration, was determined to be linear for the first 5-7 min of incubation. Thus, for calculation of optimal $\mathrm{Ca}$ efflux, the efflux occurring over the first $3 \mathrm{~min}$ of incubation was used, unless otherwise stated. To avoid problems 
that arise with the exlusive use of isotopes for flux measurements, in three experiments $\mathrm{Ca}$ was determined by atomic absorption so that there could be accurate evaluation of total calcium present in a sample at a given time. Duplicates were not done but the three experiments noted were comparable in final results. Samples for atomic absorption were ashed and incinerated in a muffle furnace, resuspended in a solution of lanthanum chloride, and then assayed in the Perkin-Elmer Model 403 Atomic Absorption Spectrophotometer (Perkin-Elmer Corp., Norwalk, Conn.) (24). Ceramic or glass crucibles have $\mathrm{Ca}$ that contaminates the sample during the ashing procedure; however, we found it possible to use a single batch of $30-\mathrm{ml}$ Vycor crucibles, using each crucible once and then discarding it (Corning Glass Works, Corning, N. Y.).

Analytic procedures. 4-ml samples containing approximately $0.3 \mathrm{ml}$ of packed ghosts were incubated at $37^{\circ} \mathrm{C}$, after which the ghosts were separated from the supernatant

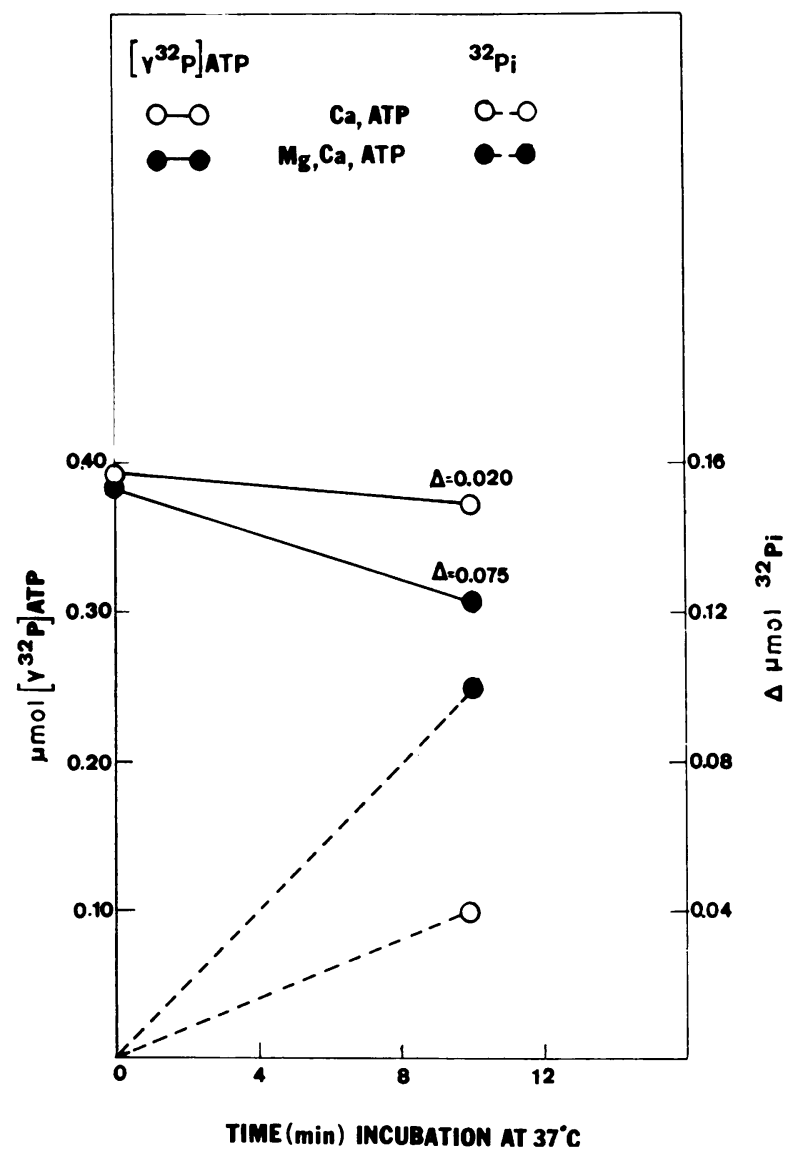

Figure $2 \mathrm{Ca}, \mathrm{Mg}$-ATPase activity is related to time of incubation at $37^{\circ} \mathrm{C}$. The left ordinate indicates the micromoles of isotopically labeled ATP residual in resealed ghosts at the time indicated (solid lines). Since there were $0.3 \mathrm{ml}$ packed ghosts in the sample, the amount of ATP present within $1 \mathrm{ml}$ of packed ghosts can be obtained by multiplying by 3.33 . The change in $\left[{ }^{32} \mathrm{P}\right] \mathrm{ATP}$ content is indicated by $\Delta$. The right ordinate indicates micromoles of ${ }^{32} \mathrm{Pi}$ produced (dotted lines). Ghosts hemolyzed with $\mathrm{Ca}$ and ATP are indicated by open circles and ghosts hemolyzed with $\mathrm{Ca}$,$\mathrm{ATP}$, and $\mathrm{Mg}$ are indicated by closed circles.
TABLE II

ATPase Activity of Resealed Ghosts as a Function of the Concentration of Mg Added to the Hemolyzing Solution*

\begin{tabular}{cc}
\hline $\begin{array}{c}\text { Mg content } \\
\text { of hemolyzing } \\
\text { solution }\end{array}$ & ATPase \\
\hline$m M$ & $\begin{array}{c}\text { nmol } \\
\text { 32Pi/min } / 10^{10} \\
\text { ghosts }\end{array}$ \\
0 & 10 \\
0.25 & 12 \\
0.50 & 17 \\
1.00 & 23 \\
2.50 & 52 \\
5.00 & 42
\end{tabular}

* The hemolyzing solution also consisted of $2.5 \mathrm{mM}$ ATP and $1.0 \mathrm{mM} \mathrm{Ca}$. The effectiveness of resealing was such that the ATP content was $1.79 \mu \mathrm{mol}$ of ATP/ml packed ghosts.

solution by centrifugation at $4^{\circ} \mathrm{C}$. The supernatant solution was analyzed for ${ }^{45} \mathrm{Ca}$ and ${ }^{32} \mathrm{Pi}$ as required. (Fig. 1). The ghost pellet was brought to a defined volume, and the number of ghosts present was determined in the Coulter Counter, Model B (Coulter Electronics Inc., Hialeah, Fla.). The time lag between removal of sample from incubation to a point when samples were ready for assay was $4 \mathrm{~min}$ with the sample held at $4^{\circ} \mathrm{C}$. Counting of ghosts is complex, particularly when Ca-containing contracted ghosts are

TABLE III

ATPase Activity of Resealed Ghosts as a Function of the Concentration of Calcium Added to the Hemolyzing Solution*

\begin{tabular}{|c|c|c|}
\hline $\begin{array}{c}\mathrm{Ca} \text { content } \\
\text { of hemolyzing } \\
\text { solution }\end{array}$ & $\begin{array}{l}\ddagger \text { Actual Ca } \\
\text { content of } \\
\text { resealed } \\
\text { ghosts }\end{array}$ & ATPase \\
\hline$m M$ & 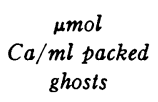 & $\begin{array}{c}n m o l \\
32 P i / m i n / 10^{10} \\
\text { ghosts }\end{array}$ \\
\hline 0 & 0 & 3 \\
\hline 0.1 & - & 4 \\
\hline 0.375 & 0.1 & 8 \\
\hline 0.75 & 0.57 & 40 \\
\hline 1.0 & 0.94 & 46 \\
\hline 2.5 & 2.80 & 26 \\
\hline 5.0 & 5.00 & 24 \\
\hline
\end{tabular}

* The hemolyzing solution also contained $2.5 \mathrm{mM} \mathrm{Mg}$ and $2.5 \mathrm{mM}$ ATP. The effectiveness of resealing was such that the ATP content of sealed ghosts varied from 1.08 to $1.41 \mu \mathrm{mol}$ ATP $/ \mathrm{ml}$ packed ghosts.

$\ddagger$ The actual calcium content of ghosts was determined experimentally from a series of parallel tubes where the $\mathrm{Ca}$ in the resealing mixture was labeled with ${ }^{45} \mathrm{Ca}$ of known specific activity, and the radioactivity of the washed ghost pellets was measured at the beginning of the incubation. 


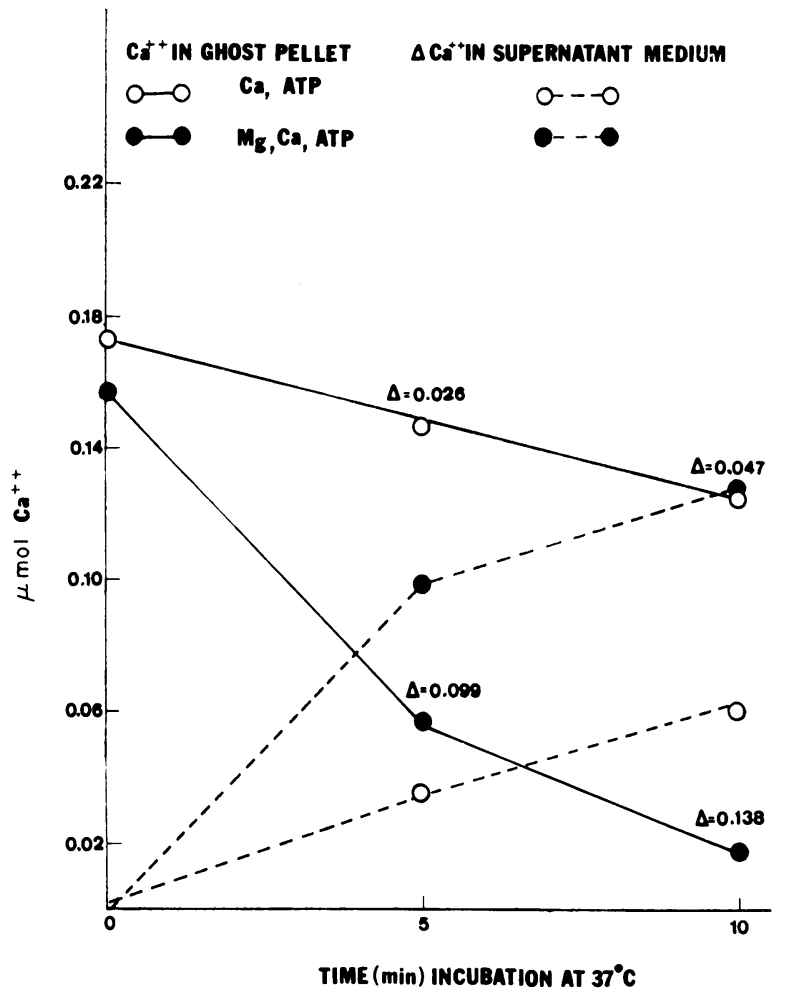

Figure 3 Efflux of $\mathrm{Ca}$ from within resealed erythrocyte ghosts incubated at $37^{\circ} \mathrm{C}$. The hemolyzing solutions consisted of $2.5 \mathrm{mM}$ ATP and $1 \mathrm{mM} \mathrm{Ca}$ (open circles), with the addition of $2.5 \mathrm{mM} \mathrm{Mg}$ (closed circles). The ordinate records micromoles of $\mathrm{Ca}$. The solid lines refer to $\mathrm{Ca}$ residual in ghosts incubated under the conditions described in Fig. 2. The dotted lines indicate the appearance of $\mathrm{Ca}$ in the supernatant medium. The symbol $\Delta$ appearing along the course of the solid lines indicates the change in micromoles of $\mathrm{Ca}$ in ghosts over the given time intervals.

involved. The procedure followed is basically that described previously (25), when the ghosts were counted in the Coulter Counter with regular confirmation by hemocytometer counting with phase microscopy. Ghosts were counted at an upper threshold setting of $0-100$ and a lower threshold setting of $0-5$, amplification $\frac{1}{2}$, aperture current $\frac{1}{2}$, in Coulter isoton diluent with an automatic diluter. Each sample was counted three or more times until there was less than $5 \%$ variation in count. A ghost hematocrit was performed in duplicate so that a mean corpuscular volume of ghosts could be calculated. No attempt was made to standardize the hematocrit of these red ghosts. Isotopic analyses for ${ }^{45} \mathrm{Ca}$, $\left[\gamma^{32} \mathrm{P}\right] \mathrm{ATP}$ and ${ }^{32} \mathrm{Pi}$ were performed on the ghost pellet. In the experiments where $\mathrm{Ca}$ flux was measured by atomic absorption, the ATP content of ghosts was determined on perchloric acid filtrates by the coupled enzyme reaction utilizing glucokinase and glucose-6-phosphate dehydrogenase (19). Ruthenium red was used to inhibit the $\mathrm{Ca}, \mathrm{Mg}-\mathrm{ATP}$ ase (16) and $\mathrm{Ca}$ efflux (26); and since it has limited capacity to penetrate plasma membranes (27), it was added during the hemolysis step at the concentrations indicated. Concentrations of ruthenium red above $120 \mu \mathrm{M}$ interfered with the ghost-sealing procedure.

Evaluation of endocytosis. Morphologic evaluation of endocytosis was performed in each experiment by phase mi- croscopy (7), and in specific circumstances by electronmicroscopy by the procedures for fixation as previously described (7). The glutaraldehyde was prepared in $\mathrm{pH} 6.7$ phosphate buffer, $45 \mathrm{mM}$ with a final osmolarity of 300 mosM.

\section{RESULTS}

ATPase activity in resealed ghosts. $\mathrm{Ca}, \mathrm{Mg}$ and $\mathrm{ATP}$ are required for endocytosis and are also the cofactors and substrate for a membrane-associated $\mathrm{Ca}, \mathrm{Mg}$-ATPase. We explored the possible relationship between ghost endocytosis and $\mathrm{Ca}, \mathrm{Mg}$-ATPase activation by comparing the optimal concentration of reactants required for each.

Measurement of ATPase activity within resealed erythrocyte ghosts is recorded in Fig. 2. Results of a single experiment typical of more than 20 are shown. The hemolyzing solution contained $1 \mathrm{mM} \mathrm{Ca}$ and 2.5 $\mathrm{mM}$ ATP to which $\left[\gamma^{32} \mathrm{P}\right] \mathrm{ATP}$ was added to provide a specific activity of $50,000 \mathrm{cpm} / \mu \mathrm{mol}$ of ATP, and, where added, $2.5 \mathrm{mM} \mathrm{Mg}$. In this experiment, the absolute amount of ATP resealed within ghosts at the beginning of the experiment ( 0 time) was the same whether $\mathrm{Mg}$ was added or omitted. After 10 min there was some decrease of $\left[\gamma^{32} \mathrm{P}\right]$ ATP within resealed ghosts in the absence of $\mathrm{Mg}$. Presumably this occurred because it was difficult to prepare ghosts totally free of $\mathrm{Mg}$. The addition of $\mathrm{Mg}$ produced an increment in $\left[\gamma^{32} \mathrm{P}\right] \mathrm{ATP}$ disappearance and a similar increase in production of ${ }^{32} \mathrm{Pi}$. The decrease in $\left[{ }^{32} \mathrm{P}\right] \mathrm{ATP}$ within ghosts during the 10 -min sampling period of incubation is shown in Fig. 2 as $\Delta\left[{ }^{32} \mathrm{P}\right]$ ATP Some of the newly generated ${ }^{32} \mathrm{Pi}$ was found in the supernatant medium, although most was recovered within the erythrocyte ghosts during the 0-10-min incubation period. In most experiments there was good correlation between disappearance of $\left[\gamma^{32} \mathrm{P}\right]$ ATP and appearance of ${ }^{32} \mathrm{Pi}$. As previously noted, monitoring of the supernatant media for leak of $\left[\gamma^{32} \mathrm{P}\right]-$ ATP was performed and less than $2 \%$ of total ATP resealed within ghosts leaked into the supernatant media during the incubation. Therefore, under conditions optimal for ghost endocytosis, there is also activation of an ATPase. Since the resealing solutions were composed of choline chloride, there was no opportunity for activation of $\mathrm{Na}, \mathrm{K}$-ATPase, or for monovalent cation activation of the $\mathrm{Ca}, \mathrm{Mg}$-ATPase (11).

The $\mathrm{Mg}$ concentration dependence of the ATPase was measured (Table II) and occurred over a range of $0.5-2.5 \mathrm{mM} \mathrm{Mg}$ added to the hemolyzing solution mixture. As previously reported (12), optimal activation occurred when $\mathrm{Mg}$ and ATP concentrations were equal. Thus for a hemolyzing solution containing 1.0 $\mathrm{mM} \mathrm{Ca}$ and $2.5 \mathrm{mM} \mathrm{ATP}$, optimal ATPase activity was observed at $\mathrm{Mg}$ levels of $2.5 \mathrm{mM}$.

The Ca concentration dependence of the ATPase (Table III) was also determined by varying the $\mathrm{Ca}$ content 
of the hemolyzing solution from 0.1 to $5.0 \mathrm{mM}$. The actual $\mathrm{Ca}$ content of the resealed ghosts at the beginning of the incubation period is also shown in Table III. There was a biphasic response of ATPase activity to an increase in the $\mathrm{Ca}$ content in the hemolyzing solution. $\mathrm{Ca}$ concentrations from $0.25 \mathrm{mM}$ to $1.0 \mathrm{mM}$ produced activation, while concentrations of $\mathrm{Ca}$ in excess of 2.5 $\mathrm{mM}$ produced inhibition. A single experiment typical of three is shown. The concentrations of $\mathrm{Mg}$ and ATP used to study this biphasic effect of $\mathrm{Ca}$ were those previously shown to provide optimal ghost endocytosis (9), although given the complex interaction of these three reactants, other results could have been obtained if we had also varied the $\mathrm{Mg}$ and ATP concentrations.

The ATPase under study in the resealed ghosts required $\mathrm{Mg}$ (Table II) and manifested a 10-12-fold increase in activity with increasing concentrations of $\mathrm{Ca}$ up to $1.0 \mathrm{mM}$ (Table III). These are the characteristics of a $\mathrm{Ca}, \mathrm{Mg}$-ATPase known to be present at the inner surface of the erythrocyte plasma membrane $(11,12)$. Therefore endocytosis and $\mathrm{Ca}, \mathrm{Mg}$-ATPase activity share a requirement for $\mathrm{Mg}$ (Table II) (9) and both phenomena are dependent on the concentration of $\mathrm{Ca}$ added to the resealing solution, with stimulation of each occurring at $\mathrm{Ca}$ concentrations up to $1.0 \mathrm{mM}$ and inhibition of each occurring at $\mathrm{Ca}$ concentrations above $2.5 \mathrm{mM}$ (9) (Table III).

Calcium efflux from resealed ghosts. The requirements for optimum ghost endocytosis are also similar to the conditions described for $\mathrm{Ca}$ efflux from resealed ghosts (12). In the experiment measuring $\mathrm{Ca}$ efflux in Fig. 3, there was no $\mathrm{Ca}$ added to the external medium and the $\mathrm{Ca}$ resealed within erythrocyte ghosts was labeled with ${ }^{45} \mathrm{Ca}$ so that the specific activity was approximately $10^{6} \mathrm{cpm} / \mu \mathrm{mol} \mathrm{Ca}$. Calculation of $\mathrm{Ca}$ efflux could be obtained by measuring either the disappearance of ${ }^{45} \mathrm{Ca}$ from the centrifuged ghost pellet or the appearance of ${ }^{45} \mathrm{Ca}$ in the supernatant medium, and both measurements were routinely used to check on the accuracy of recovery of ghosts and supernatant medium (Fig. 3). Addition of $2.5 \mathrm{mM} \mathrm{Mg}$ led to a threefold or greater increase in $\mathrm{Ca}$ efflux and this result therefore paralleled the increase in ATPase activity that also occurred upon $\mathrm{Mg}$ addition. These results are consistent with previous proposals linking $\mathrm{Ca}$ efflux in erythrocytes and their ghosts to a Ca,Mg-ATPase $(12-14,21)$.

Flux measurements with radioisotopes have the advantage of simplicity and ease of analysis; however, they are subject to a variety of sources of error. Therefore, $\mathrm{Ca}$ efflux experiments were repeated with atomic absorption spectrophotometry to measure actual $\mathrm{Ca}$ content within ghosts at the end of the incubation period. Three experiments were performed wherein atomic absorption was used in parallel with measurements of

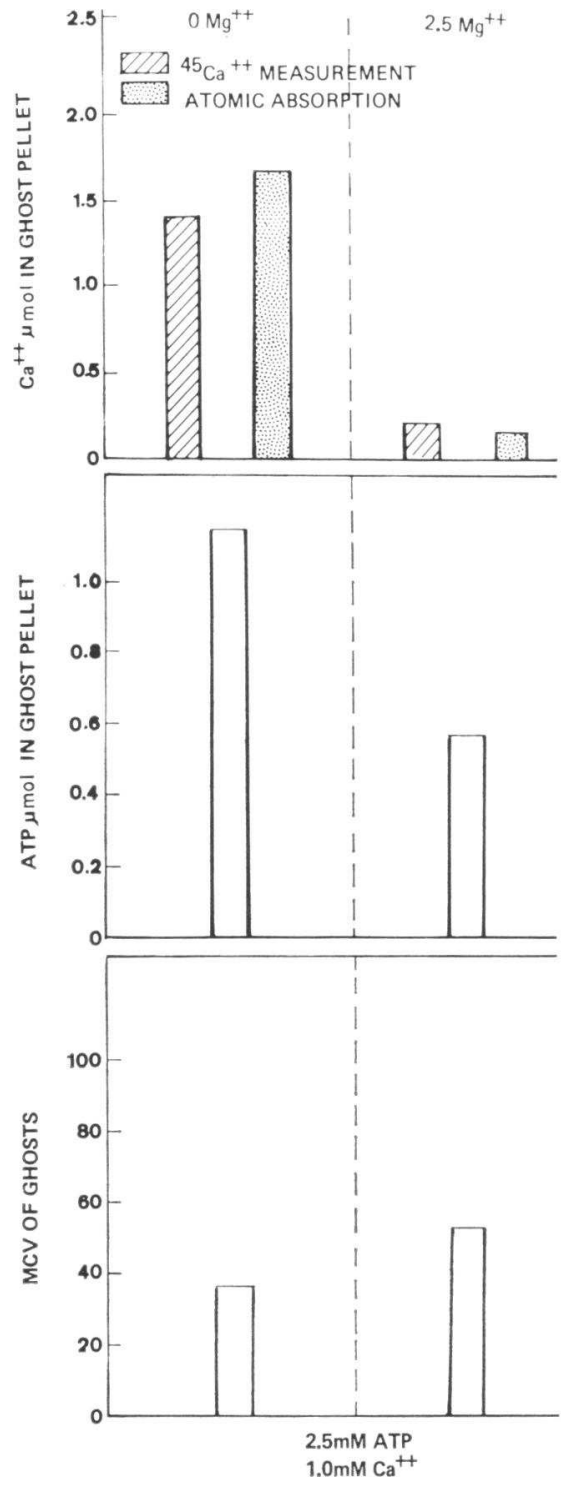

Figure $4 \mathrm{Ca}$ movements were measured by atomic absorption spectrophotometry and radioisotopically. The hemolyzing solutions contained $1.0 \mathrm{mM} \mathrm{Ca}$ and $2.5 \mathrm{mM}$ ATP without (left side) and with (right side) the addition of $2.5 \mathrm{mM} \mathrm{Mg}$. Since relatively large samples are required for atomic absorption measurements, $2 \mathrm{ml}$ of packed ghosts were used. The results in the figure are those recorded per $2 \mathrm{ml}$ packed ghosts after the equilibration, resealing, washing, and subsequent incubation at $37^{\circ} \mathrm{C}$ for $15 \mathrm{~min} . \mathrm{MCV}$, mean corpuscular volume.

${ }^{45} \mathrm{Ca}$ flux. In the single experiment shown in Fig. 4, Ca disappearance from ghosts was similar whether measured by atomic absorption or by determination of ${ }^{45} \mathrm{Ca}$ isotopic activity. Furthermore, after the incubation period, there was a distinct decrease of ATP in the $\mathrm{Mg}$ containing resealed ghost pellet. The conditions in these experiments were parallel to those described above, 


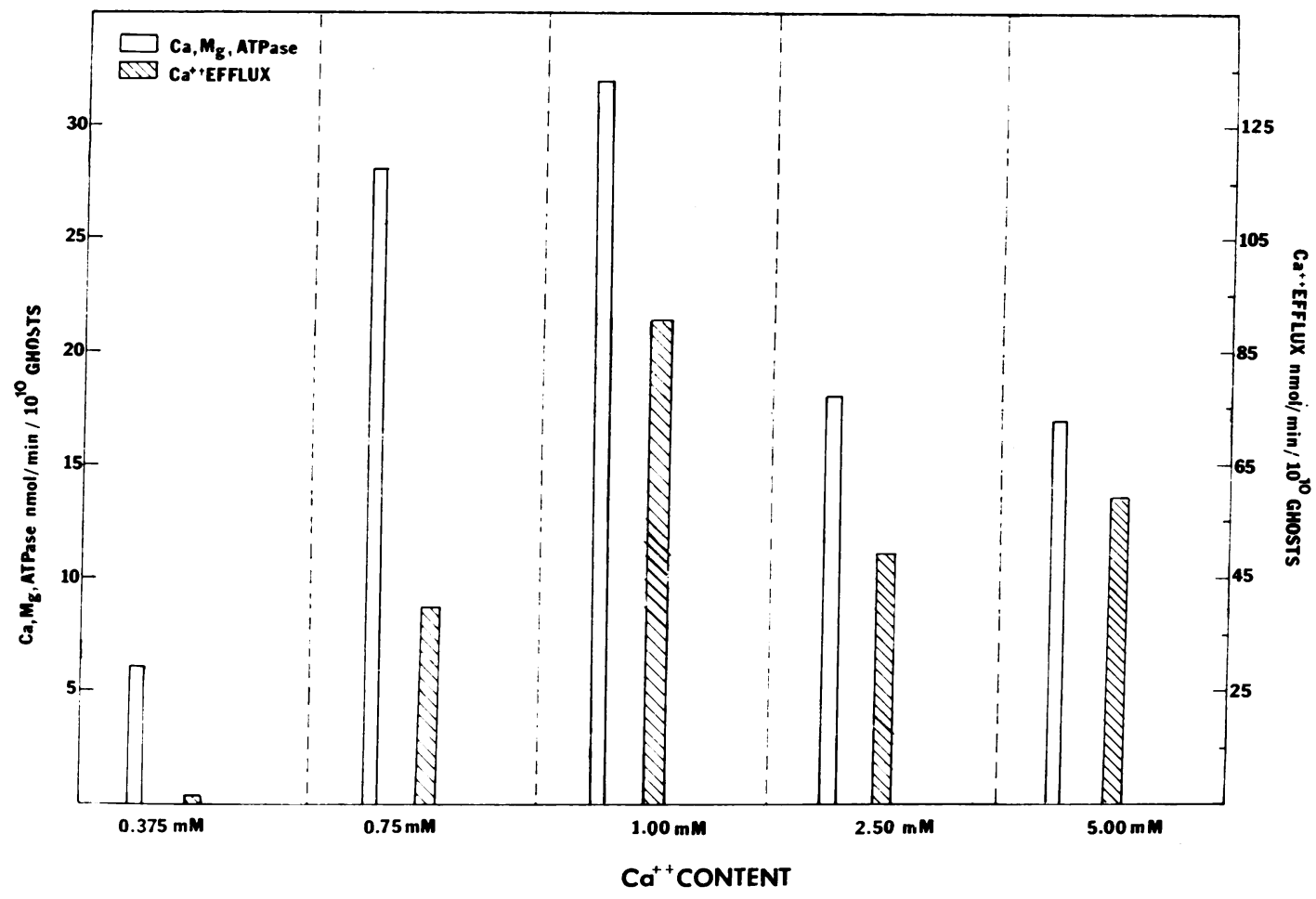

Figure $5 \mathrm{Ca}, \mathrm{Mg}$-ATPase and $\mathrm{Ca}$ efflux as a function of the external $\mathrm{Ca}$ concentration of the hemolyzing solution. The $\mathrm{Ca}$ content of the hemolyzing solution is recorded on the abscissa for each panel. The left ordinate indicates the $\mathrm{Ca}, \mathrm{Mg}$-ATPase activity (open bars) whereas the right ordinate indicates $\mathrm{Ca}$ efflux from ghosts (hatched bars).

where it could be shown that less than $2 \%$ of resealed ATP leaked from ghosts during the incubation period. Therefore it was unlikely that the ATP disappearance from ghosts represented ATP leak and more likely that ATP hydrolysis accounted for the decrease in enzymatically measurable ATP. These studies showed that upon addition of $\mathrm{Mg}$ to the resealing solution there was a substantial movement of $\mathrm{Ca}$ out of ghosts concomitant with a reduction of ATP content of ghosts, thus confirming by alternative methods the results obtained with ${ }^{45} \mathrm{Ca}$ and $\left[{ }^{32} \mathrm{P}\right] \mathrm{ATP}$. It is of interest that part of the sharp reduction of mean corpuscular volume seen with ghosts incubated in $\mathrm{Ca}$ alone is blocked by the simultaneous addition of $\mathrm{Mg}$.

$\mathrm{Ca}$ efflux as a function of the varying concentration of $\mathrm{Ca}$ in the hemolyzing solution was then determined. An experiment is shown in Fig. 5 where $\mathrm{Ca}, \mathrm{Mg}$-ATPase activity and $\mathrm{Ca}$ efflux were measured as a function of the $\mathrm{Ca}$ content of the hemolyzing solution. Maximal activation of both $\mathrm{Ca}$ efflux and $\mathrm{Ca}, \mathrm{Mg}$-ATPase occurred at $\mathrm{Ca}$ concentrations of $0.75-1.00 \mathrm{mM}$ with a biphasic aspect to the curve. Thus the three phenomena under study, endocytosis, $\mathrm{Ca}, \mathrm{Mg}$-ATPase, and $\mathrm{Ca}$ efflux, share a requirement for $\mathrm{Mg}$ and show nearly identical responses to addition of $\mathrm{Ca}$ over a concentration range of approximately $0.25-5.0 \mathrm{mM}$.

17 experiments were performed in which $\mathrm{Ca}$ efflux was measured in parallel with $\mathrm{Ca}, \mathrm{Mg}$-ATPase activity at optimal conditions for each. These values were used to calculate a $\mathrm{Ca} / \mathrm{P}$ ratio that represents the number of moles of $\mathrm{Ca}$ transferred out of ghosts per mole of ATP hydrolyzed to $\mathrm{ADP}$. The mean $\pm \mathrm{SD} \mathrm{Ca} / \mathrm{P}$ ratio calculated was $1.24 \pm 0.48$ for 17 determinations, and this value is in substantial agreement with values of $0.856,1.27$, and 1.39 recently reported by Schatzmann (21).

Morphologic appearance of endocytosis in relation to the activation of Ca,Mg-ATPase and to Ca efflux ( $T a$ ble IV, Fig. 6). Experiments were designed to measure $\mathrm{Ca}, \mathrm{Mg}$-ATPase and $\mathrm{Ca}$ efflux simultaneously while monitoring endocytosis by electron microscopy. Interpretation of the onset and extent of endocytosis was made independently on duplicate coded samples. In the absence of added $\mathrm{Mg}$, endocytosis did not occur $(7,9)$ and addition of $\mathrm{Ca}$ and $\mathrm{ATP}$ without $\mathrm{Mg}$ produced constricted ghosts (28-30) (Fig. 6A) with belllike projections. Addition of $\mathrm{Mg}$ resulted in the activation of $\mathrm{Ca}, \mathrm{Mg}$-ATPase and efflux of $\mathrm{Ca}$ from within re- 
sealed ghosts (Table IV) with a $\mathrm{Ca} / \mathrm{P}$ ratio in this experiment of 0.95 (Table IV). However, despite the fact that the $\mathrm{Ca}, \mathrm{Mg}$-ATPase was activated and $\mathrm{Ca}$ was being extruded (Table IV), there was little morphologic alteration for $7 \mathrm{~min}$ (Fig. 6B, C, and D). Ca, MgATPase activity was relatively stable over the incubation period at $44-50 \mathrm{nmol}{ }^{32} \mathrm{Pi} / \mathrm{min}$ per $10^{10}$ ghosts. Ca efflux was stable for the first $7 \mathrm{~min}$ and paralleled $\mathrm{Ca}, \mathrm{Mg}$ ATPase activity at approximately $46 \mathrm{nmol} \mathrm{Ca} / \mathrm{min}$ per $10^{10}$ ghosts. During the last 8 min of incubation $\mathrm{Ca}$ efflux declined to a value of 28 , perhaps as a consequence of a decreased intracellular Ca content available for efflux. As a consequence of decreasing content of intra-ghost $\mathrm{Ca}$, the activity of the $\mathrm{Ca}, \mathrm{Mg}$-ATPase should have also decreased (Fig. 5). It may be that an amount of $\mathrm{Ca}$ sufficient to continue to stimulate the $\mathrm{Ca}, \mathrm{Mg}$-ATPase for an additional $8 \mathrm{~min}$ had been bound to rate-controlling sites of the enzyme at the inner wall of the erythrocyte membrane. However, samples taken for electron microscopy at 0,3 , and $7 \mathrm{~min}$ in this and two other experiments never revealed endocytosis, while there was evidence of $\mathrm{Ca}, \mathrm{Mg}$-ATPase activity and $\mathrm{Ca}$ efflux both occurring optimally during this initial 7-min of incubation. Endocytosis appeared after $15 \mathrm{~min}$ of incubation in Mg-containing ghosts (compare Fig. 6A and $\mathrm{E}$ ) and then in almost every ghost (Fig. 6E, and F). By the time endocytosis occurred, the Ca-induced constriction had essentially disappeared. This lag between extensive extrusion of $\mathrm{Ca}$ and continuous $\mathrm{Ca}, \mathrm{Mg}$ ATPase action on the one hand and endocytosis on the other was reproducible in two other experiments. In an additional experiment, samples were taken at $0,3,8,10$, 13 , and $16 \mathrm{~min}$ and showed a gradual increase in endocytosis from 10 to $16 \mathrm{~min}$, but no endocytosis before 7 min.

Inhibition of endocytosis (Fig. 7, Table V). It was then important to determine if an inhibitor of the $\mathrm{Ca}$ transport system or of $\mathrm{Ca}, \mathrm{Mg}$-ATPase would also block endocytosis. Ruthenium red has been reported to be both an inhibitor of $\mathrm{Ca}$ transfer (26) and of $\mathrm{Ca}, \mathrm{Mg}$ ATPase (16). Accordingly, ruthenium red was resealed within erythrocyte ghosts and it was determined in four experiments that there was a log concentrationdependent inhibition of both $\mathrm{Ca}$ efflux and $\mathrm{Ca}, \mathrm{Mg}$-ATPase with $50 \%$ inhibition of each function occurring at a ruthenium red concentration in the hemolyzing solution of approximately $60-80 \mu \mathrm{M}$.

Coded samples were prepared for electronmicroscopy and the interpretations were rendered independently by two observers. It can be seen (Fig. 7, Table V) that inhibition of $\mathrm{Ca}, \mathrm{Mg}$-ATPase and $\mathrm{Ca}$ efflux by ruthenium red was accompanied by extensive inhibition of endocytosis. When $100 \mu \mathrm{M}$ ruthenium red was used, endocytosis was totally inhibited while there was still
TABLE IV

ATPase and Ca Efflux Concomitants of Endocytosis

\begin{tabular}{rcc}
\hline Time & $\begin{array}{c}\text { ATP content } \\
\text { of ghosts }\end{array}$ & $\begin{array}{c}\text { Ca content } \\
\text { of ghosts }\end{array}$ \\
\hline min & $\begin{array}{c}\text { nmol } / \mathrm{ml} \\
\text { packed ghosts }\end{array}$ & $\begin{array}{c}\text { nmol/ml } \\
\text { packed ghosts }\end{array}$ \\
0 & 2,080 & 605 \\
3 & 1,930 & 426 \\
7 & 1,740 & 281 \\
15 & 1,390 & 58 \\
\hline
\end{tabular}

The resealing solution consisted of $2.5 \mathrm{mM} \mathrm{ATP}, 1.0 \mathrm{mM} \mathrm{Ca}$, and $2.5 \mathrm{mM} \mathrm{Mg}$.

substantial residual activity of $\mathrm{Ca}, \mathrm{Mg}$-ATPase and its linked $\mathrm{Ca}$ efflux. The value for the residual $\mathrm{Ca}$ in the $35-\mu \mathrm{M}$ ruthenium red sample (Table V) was lower than that for the parallel control sample because the resealing of $\mathrm{Ca}$ was somewhat lower in the $35-\mu \mathrm{M}$ ruthenium red sample at zero time in this experiment but the $\mathrm{Ca}$ efflux rate was nevertheless linear over the initial 7 min of incubation.

Effect of prostaglandins $(P G) E_{1}$ and $E_{2}$ on erythrocyte ghost endocytosis, Ca efflux, and Ca,Mg-ATPase. Prostaglandins $E_{1}$ and $E_{2}$ have been shown to affect the deformability characteristics of intact erythrocytes (31). Since the deformability of the erythrocyte is under metabolic control, represented in part by erythrocyte ATP content and in part by its $\mathrm{Ca}$ content $(32,33)$ it was hypothesized that $\mathrm{PGE}_{1}$ and $\mathrm{PGE}_{2}$ might exert their membrane effects by perturbing either $\mathrm{Ca}$ efflux, endocytosis, or the membrane-associated $\mathrm{Ca}, \mathrm{Mg}$-ATPase. We attempted to determine if prior incubation of intact erythrocytes with prostaglandins $E_{1}$ and $E_{2}$ or if addition of prostaglandins $E_{1}$ and $E_{2}$ to the resealing solution altered the capacities for endocytosis, $\mathrm{Ca}$ efflux, and $\mathrm{Ca}, \mathrm{Mg}$-ATPase of the subsequently prepared resealed ghosts. At the concentrations of prostaglandins $E_{1}$ and $E_{2}$ first used $\left(10^{-10} \mathrm{M}\right)$, there was no consistent effect on endocytosis, $\mathrm{Ca}$ efflux, or activity of $\mathrm{Ca}, \mathrm{Mg}$ ATPase. Altering prostaglandin concentration to $10^{-8}$ or $10^{-11} \mathrm{M}$ produced no change. This situation held whether the prostaglandins were preincubated with intact erythrocytes or were added during the resealing of ghosts. Variation of $\mathrm{Mg}$ concentration from 0 to $2.5 \mathrm{mM}$ and $\mathrm{Ca}$ concentration from 0 to $1.0 \mathrm{mM}$ brought out no prostaglandin-mediated effect.

\section{DISCUSSION}

The interplay of the three reactants, $\mathrm{Ca}, \mathrm{Mg}$, and ATP, is important not only for ghost endocytosis but is critical in determining the deformability characteristics of erythrocyte ghosts (33). These three materials are required for activation of a Ca, Mg-ATPase (11-13) and 


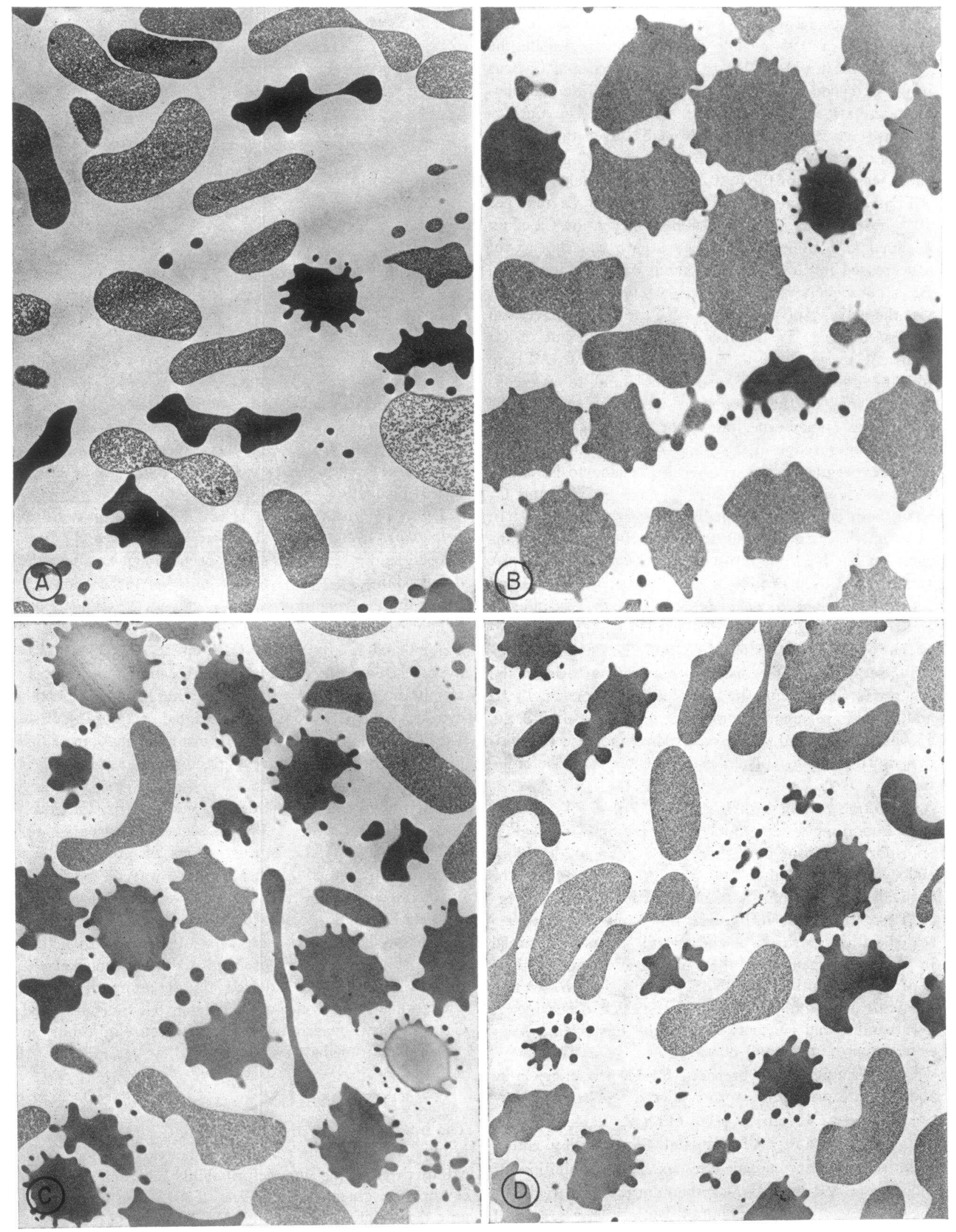

16 S. L. Schrier, K. G. Bensch, M. Johnson, and I. Junga 


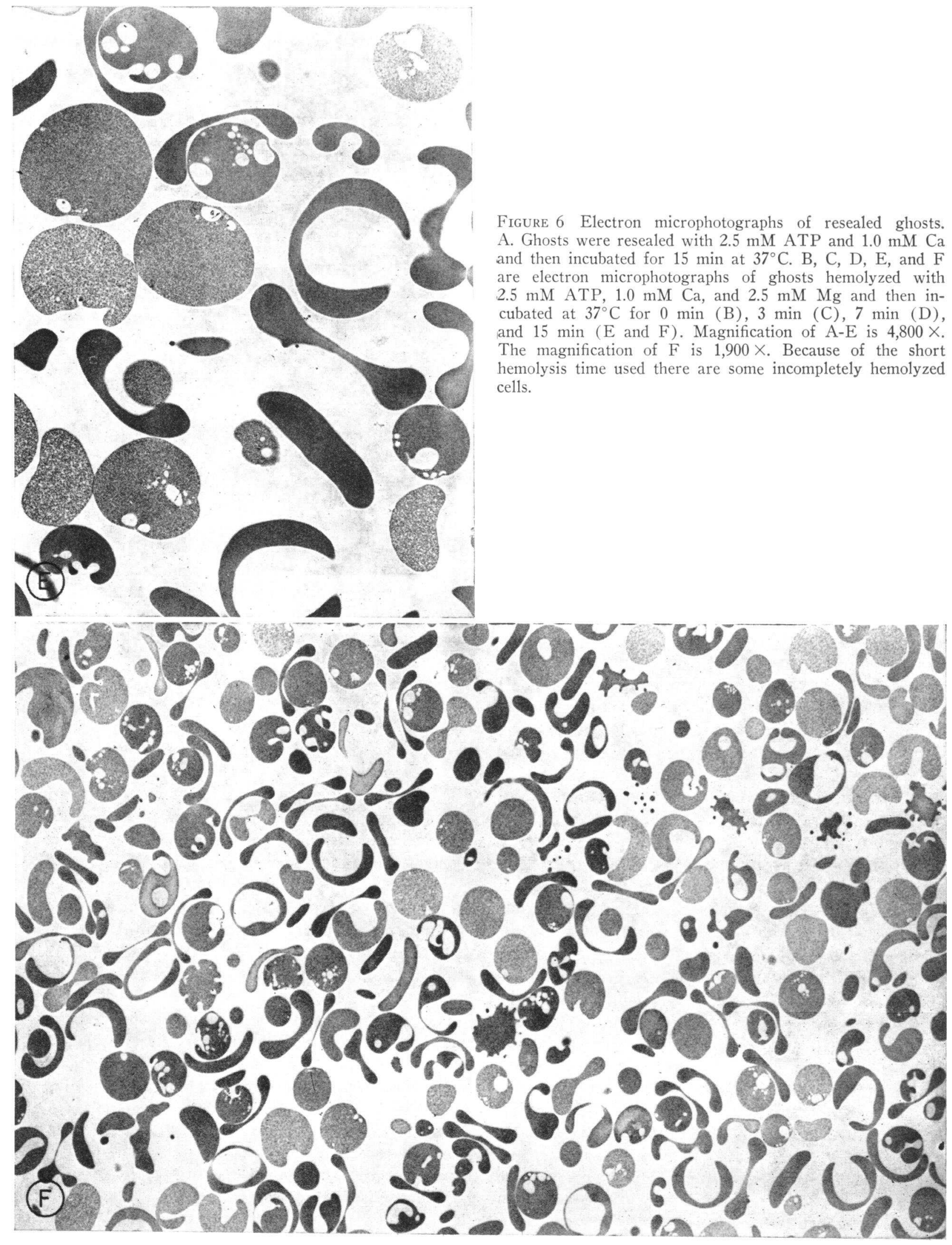


TABLE V

Effect of Ruthenium Red on Ca, Mg-ATPase, Ca Efflux, and Endocytosis

\begin{tabular}{ccccccc}
\hline & & & \multicolumn{3}{c}{$\begin{array}{c}\text { Ca content of } \\
\text { ghosts after } \\
15 \text { min of } \\
\text { incubation }\end{array}$} & $\begin{array}{c}\text { Endocytosis } \\
\text { scores }\end{array}$ \\
& Ca, Mg-ATPase & Ca efflux & $\%$ & \multicolumn{2}{c}{ nmol/1010 ghosts } \\
Control & $*$ & $\%$ & & $\%$ & 69 & 105 \\
$35 \mu \mathrm{M}$ ruthenium red & 61 & 100 & 43 & 100 & 51 & 27 \\
$70 \mu \mathrm{M}$ ruthenium red & 37 & 60 & 33 & 76 & 159 & 8 \\
$100 \mu \mathrm{M}$ ruthenium red & 27 & 44 & 26 & 60 & 168 & 0 \\
\hline
\end{tabular}

* Units same as Table II for ATPase.

$\ddagger$ Efflux rate was calculated during the first $3 \mathrm{~min}$ of incubation at $37^{\circ} \mathrm{C}$ where the rate was linear with respect to time and is recorded as nanomoles of $\mathrm{Ca}$ leaving ghosts per minute per $10^{10}$ ghosts. $\S$ A rough approximation of endocytosis was made by counting endocytic vacuoles in resealed ghosts in fields of comparable erythrocyte density on four photographic prints of different fields.

for the linked unidirectional efflux of $\mathrm{Ca}$ from within resealed ghosts (12-14). The evidence relating erythrocyte ghost $\mathrm{Ca}, \mathrm{Mg}$-ATPase and $\mathrm{Ca}$ efflux is by now quite compelling (21). Because of the similarity in required reactants and because of the similar biphasic response of endocytosis, $\mathrm{Ca}, \mathrm{Mg}-\mathrm{ATPase}$, and $\mathrm{Ca}$ efflux to increasing concentration of $\mathrm{Ca}$ (11), we explored the possibility that the $\mathrm{Ca}, \mathrm{Mg}-\mathrm{ATPa} e$ and the efflux of $\mathrm{Ca}$ might have an important role in energized ghost endocytosis.

In the experiments reported now it appears that the same strict requirement for $\mathrm{Mg}$ exists for activation of $\mathrm{Ca}, \mathrm{Mg}$-ATPase, Ca efflux, and endocytosis (Table II, Fig. 3). Furthermore, the biphasic response to increasing $\mathrm{Ca}$ content in the resealing mixture is essentially identical for optimal endocytosis (9), Ca, Mg-ATPase activity, and $\mathrm{Ca}$ efflux (Fig. 5).

In pursuing the apparent parallelism between endocytosis, $\mathrm{Ca}, \mathrm{Mg}$-ATPase, and $\mathrm{Ca}$ efflux we studied the role of ruthenium red. Ruthenium red is reported to be an effective inhibitor of the $\mathrm{Ca}, \mathrm{Mg}$-ATPase of erythrocyte ghosts (16), and we confirmed this observation (Table V). The 50\% inhibition value obtained in our study is $60-80 \mu \mathrm{M}$, substantially greater than the value of $10 \mu \mathrm{M}$ previously reported (16). However, in that study unsealed membranes were used, whereas we studied resealed ghosts (Methods), where it could be anticipated that problems of continued access of inhibitor molecules to critical sites would arise. Ruthenium red also inhibits mitochondrial Ca transport (26) and effectively blocked Ca efflux from resealed ghosts (Table $\mathrm{V})$. There was almost parallel ruthenium red inhibition of $\mathrm{Ca}, \mathrm{Mg}$-ATPase and $\mathrm{Ca}$ efflux and it was not possible to determine from this sort of analysis which, if either, was the prior event. Of critical importance was the sensitivity of endocytosis to ruthenium red inhibition (Fig. 7). In fact ruthenium red totally blocked endo- cytosis at concentrations that left $30-40 \%$ residual $\mathrm{Ca}$,$\mathrm{Mg}$-ATPase activity linked to $\mathrm{Ca}$ efflux (Table V). It is possible that ruthenium red combines with a membrane component which may be of major importance in energized endocytosis and which may also serve to link $\mathrm{Ca}, \mathrm{Mg}$-ATPase with a $\mathrm{Ca}$ transposing or translocating system. The studies of Luft (27) have shown that ruthenium red appears to bind to acid mucopolysaccharides and is generally excluded by plasma membranes. When incubated with intact erythrocytes, it can be shown to stain a thin layer of the plasma membrane with a pattern showing some extension into the membrane substance proper, as though there were a degree of porosity. Under certain circumstances ruthenium red may also bind to lipid, particularly acid phospholipids, so that membrane components susceptible to ruthenium red would include lipids as well as glycoproteins. Of interest is that ruthenium red seems to localize at sites where mechanical forces are proven or suspected, as along collagen fibers and particularly at the myotendinal junction. Thus the observation that ruthenium red appears to be a more potent inhibitor of endocytosis than $\mathrm{Ca}$ efflux or $\mathrm{Ca}, \mathrm{Mg}-\mathrm{ATPase}$ suggests that the inhibitor may attack a membrane component which is involved in the mechanical aspects of endocytosis and which may also link the ATP-hydrolyzing system with a Ca-translocating system.

The biphasic response of the three phenomena under consideration to variations in $\mathrm{Ca}$ concentration is of interest, with the response changing from stimulation to inhibition over a concentration range of $0.1-2.0 \mathrm{mM}$ (9) (Fig. 5). It is conceivable that a single class of molecule responds to increases in $\mathrm{Ca}$ concentration in a biphasic manner. Thus it has been observed (11) that increasing concentrations of $\mathrm{Ca}$ interfere with the binding of required $\mathrm{Mg}$, thereby producing inhibition of $\mathrm{Ca}, \mathrm{Mg}$-ATPase. However, the actions of calcium are 


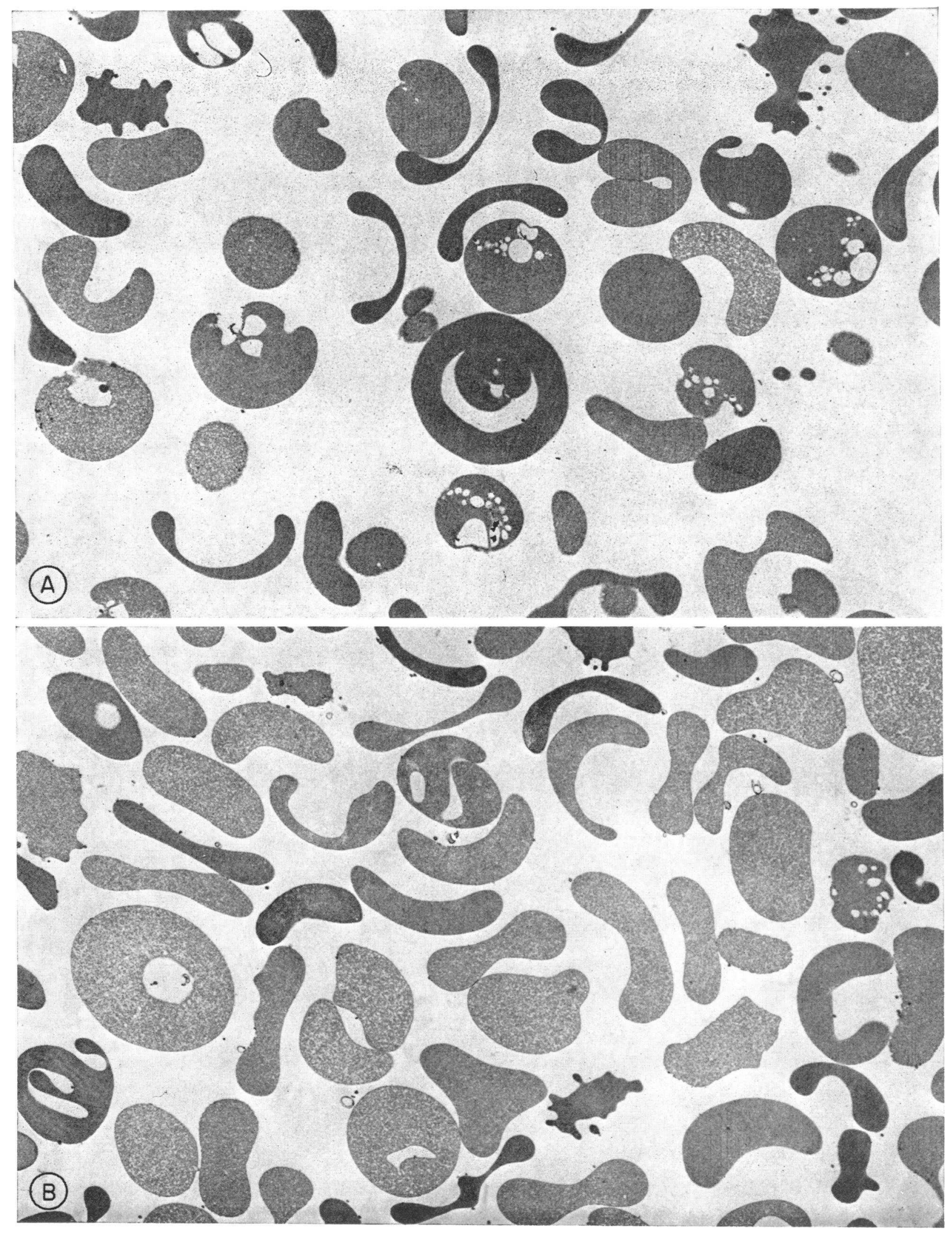

Endocytosis in Erythrocyte Ghosts 


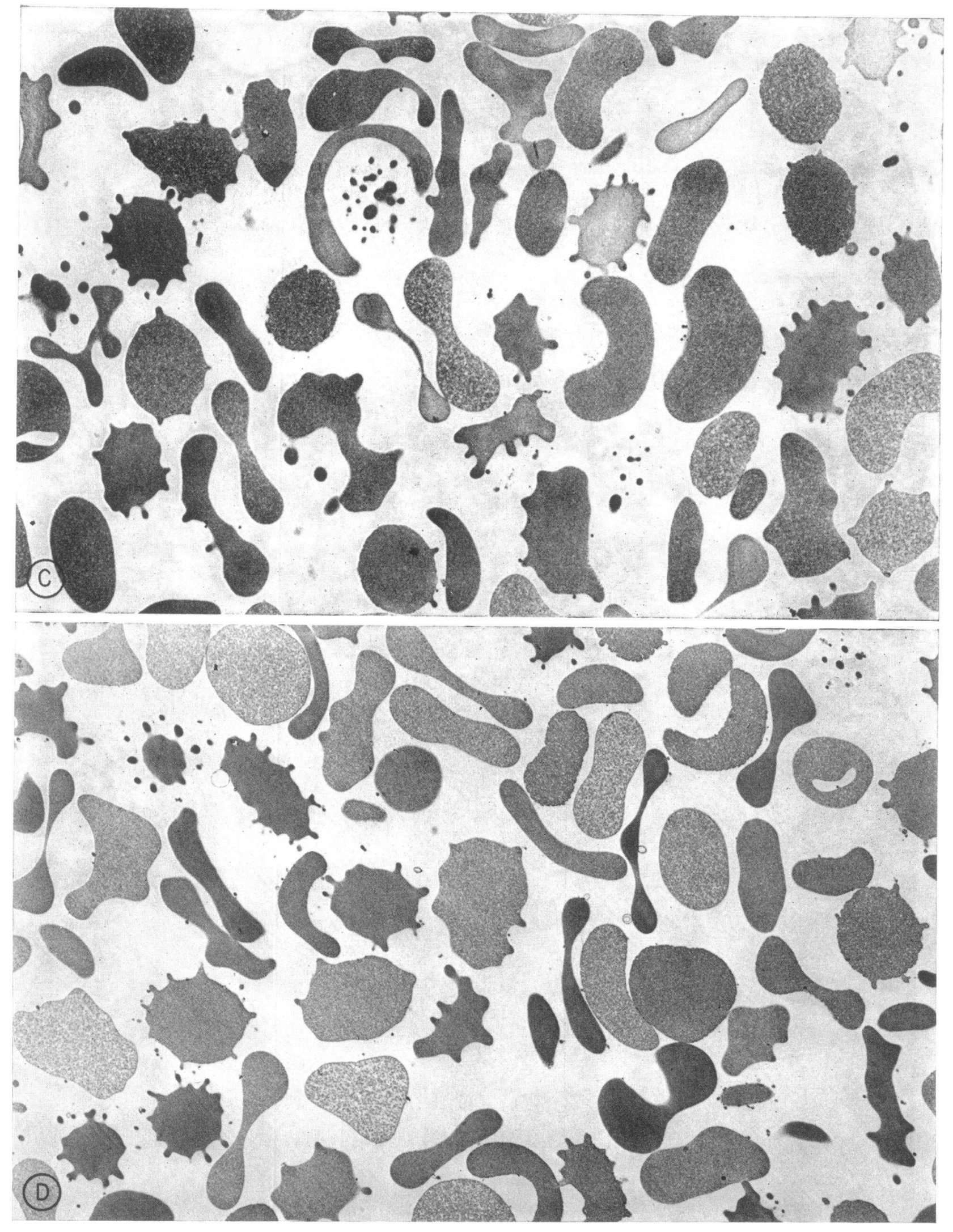


complex at concentrations greater than $1 \mathrm{mM}$ and it also has the capacity to aggregate and otherwise alter erythrocyte and other membrane proteins $(34,35)$. Therefore certain concentrations of $\mathrm{Ca}$ might by action on one class of membrane component activate endocytosis, $\mathrm{Ca}$ efflux, and $\mathrm{Ca}, \mathrm{Mg}-\mathrm{ATPase}$, whereas higher concentrations of $\mathrm{Ca}$ could precipitate other specific membrane proteins $(35,36)$, thus producing rigidity and perhaps loss of function that would now interfere with the mechanical aspects of endocytosis, Ca, Mg-ATPase, and $\mathrm{Ca}$ efflux.

While there is substantial similarity between endocytosis and $\mathrm{Ca}$ efflux and $\mathrm{Ca}, \mathrm{Mg}$-ATPase, there are differences. It was reported that efflux of $\mathrm{Ca}$ from resealed ghosts could be energized equally well by ATP, CTP, and UTP (14), whereas CTP and UTP were less than one third as effective as ATP in energizing ghost endocytosis (9).

Study of the possible role of prostaglandin $E_{1}$ and $E_{2}$ was prompted by their reported ability to alter erythrocyte membrane deformability (31) when $\mathrm{Ca}$ is added to the suspending media (36). Our studies revealed no effect of prostaglandin $\mathrm{E}_{1}$ and $\mathrm{E}_{2}$ on endocytosis, $\mathrm{Ca}$ efflux, or $\mathrm{Ca}, \mathrm{Mg}$-ATPase, in the concentration range that produces (36) small but highly reproducible membrane alterations.

If endocytosis were a direct reflection of $\mathrm{Ca}, \mathrm{Mg}$ ATPase activation or of $\mathrm{Ca}$ extrusion, we would have expected to see endocytic vacuoles forming immediately upon resealing and incubation at $37^{\circ} \mathrm{C}$. However, while $\mathrm{Ca}, \mathrm{Mg}$-ATPase was steadily active over a $15-\mathrm{min}$ period (Table IV) (Fig. 6) and optimal $\mathrm{Ca}$ efflux occurred over an initial 7-min period (Table IV), no endocytosis was seen until more than $7 \mathrm{~min}$ had elapsed. The lag between $\mathrm{Ca}$ efflux and $\mathrm{Ca}, \mathrm{Mg}$-ATPase on one hand and endocytosis on the other suggests that a slower mechanicochemical event could have preceeded endocytosis.

Alternatively, it could be proposed that the time lag served only to displace enough $\mathrm{Ca}$ from the ghost membrane so that Mg-ATP could produce endocytosis. From the data in Table IV it could be argued that when the ghost $\mathrm{Ca}$ content dropped below $0.281 \mu \mathrm{mol} / \mathrm{ml}$, endocytosis could occur, and therefore, the optimal $\mathrm{Ca}$ concentrations for endocytosis are lower than those for $\mathrm{Ca}$ efflux. Ghost $\mathrm{Ca}$ contents of $0.28 \mu \mathrm{mol} / \mathrm{ml}$ or less can be achieved by hemolyzing ghosts in the presence of approximately $0.5 \mathrm{mM} \mathrm{Ca}$ (Table Ic and Table III) or less; however, such conditions result in decreasing endocytosis, paralleling the decrease in $\mathrm{Ca}$ concentration (9). Furthermore, it can be seen in Table $\mathrm{V}$ that use of $35 \mu \mathrm{M}$ ruthenium red only modestly impaired $\mathrm{Ca}$ efflux and that after $15 \mathrm{~min}$ of incubation, the $\mathrm{Ca}$ content of the ghosts so treated was similar to that of the control; however, despite the low $\mathrm{Ca}$ content, endocytosis was distinctly impaired. Therefore the absolute level of $\mathrm{Ca}$ in ghosts appears to exert some control over the extent of endocytosis, which, however, seems to relate more directly to the extent of ATPase activity and $\mathrm{Ca}$ translocation.

Our morphologic studies (Fig. 6) confirm the previously described Ca-linked constriction of erythrocyte ghosts (28-30). In the absence of added $\mathrm{Mg}$, ghosts containing $\mathrm{Ca}$ and $\mathrm{ATP}$ remained in a sharply constricted form for at least $15 \mathrm{~min}$ of incubation at $37^{\circ} \mathrm{C}$ (Fig. 6A). However, upon addition of $\mathrm{Mg}$. which activates the $\mathrm{Ca}, \mathrm{Mg}$-ATPase and $\mathrm{Ca}$ efflux (Fig. 6E and Table IV), there is distinct loss of ghost constriction, which is time-dependent and coincides with the efflux of most of the $\mathrm{Ca}$ from ghosts. In contrast to endocytosis, ghost constriction appears to relate almost directly to the absolute amount of intra-ghost $\mathrm{Ca}$ present at a given time. When $35 \mu \mathrm{M}$ ruthenium red was used (Table V, Fig. 7B), there was impaired endocytosis, but $\mathrm{Ca}$ efflux was well enough preserved to result in a sharp reduction of intracellular $\mathrm{Ca}$ in $15 \mathrm{~min}$ and a substantial reversal of constricted ghost forms. Therefore, the proposed $\mathrm{Ca}$-activated contractile protein is not extensively affected by ruthenium red.

Ghost endocytosis, with its dependence on $\mathrm{Ca}, \mathrm{Mg}$, and ATP and its apparent relationship to $\mathrm{Ca}, \mathrm{Mg}-\mathrm{ATP}-$ ase, and $\mathrm{Ca}$ translocation, seems to be similar to the more general phenomenon of cell membrane fusion (37). In a recent review Poste and Allison (37) note that a variety of forms of cell membrane fusion, including pinocytosis, release of secretory granules, and virusinduced cell fusion, have similar biochemical characteristics, consisting of $\mathrm{Ca}, \mathrm{Mg}$-ATPase activation, parallel displacement of $\mathrm{Ca}$, and inhibition of the phenomenon by excess $\mathrm{Ca}$.

If endocytosis is thought of as simplistically consisting of a membrane invagination followed by contraction of the mouth of the invagination and subsequent membrane resealing $(1,2)$, one could hypothesize that the initial membrane expansion and inward buckling involves a degree of membrane deformability associated wtih $\mathrm{Mg}$ and ATP (33), that the contraction of the mouth of the invaginated membrane segment is perhaps mediated by a Ca-stimulated contractile protein (thus accounting in part for the $\mathrm{Ca}$ enhancement of endocytosis), and that the fusion of the endocytic vacuole is

FIGURE 7 Electron microphotographs of erythrocyte ghosts hemolyzed with $2.5 \mathrm{mM}$ ATP, $1.0 \mathrm{mM} \mathrm{Ca}$, and $2.5 \mathrm{mM} \mathrm{Mg}$ and then incubated for $15 \mathrm{~min}$ at $37^{\circ} \mathrm{C}$. No ruthenium red was added in $\mathrm{A}, 35 \mu \mathrm{M}$ ruthenium red was added to the hemolyzing solution of $\mathrm{B}, 70 \mu \mathrm{M}$ ruthenium red to $\mathrm{C}$, and $100 \mu \mathrm{M}$ ruthenium red to $\mathrm{D}$. Magnification in all is $4,900 \times$. 
controlled by mechanisms related to $\mathrm{Ca}, \mathrm{Mg}$-ATPase and $\mathrm{Ca}$ translocation, as are other examples of plasma membrane fusion (37).

\section{ACKNOWLEDGMENTS}

This project was supported by National Institutes of Health Grant S RO1 AM 13682.

\section{REFERENCES}

1. Lucy, J. A. 1973. The fusion of cell membranes. Hosp. Pract. 8(Sept.) : 93-101.

2. Trump, B. F. 1973. The network of intracellular membranes. Hosp. Pract. 8(Oct.): 111-121.

3. Holroyde, C. P., F. A. Oski, and F. H. Gardner. 1969. The "pocked" erythrocyte. N. Engl. J. Med. 281: 516520.

4. Kent, G., O. T. Minick, F. I. Volini, and E. Orfei. 1966. Autophagic vacuoles in human red cells. Am. J. Pathol. 48: 831-857.

5. Holroyde, C. P., and F. H. Gardner. 1970. Acquisition of autophagic vacuoles by human erythrocytes: physiological role of the spleen. Blood. 36: 566-575.

6. Ginn, F. L., P. Hochstein, and B. F. Trump. 1969. Membrane alterations in hemolysis. Internalization of plasmalemma induced by primaquine. Science (Wash. D. C.). $164: 843-845$.

7. Ben-Bassat, I., K. G. Bensch, and S. L. Schrier. 1972. Drug-induced erythrocyte membrane internalization. $J$. Clin. Invest. 51 : 1833-1844.

8. Penniston, J. T., and D. E. Green. 1968. The conformational basis of energy transformations in membrane systems. IV. Energized states and pinocytosis in erythrocyte ghosts. Arch. Biochim. Biophys. 128: 339-350.

9. Schrier, S. L., I. Junga, and M. Seeger. 1973. Vacuole formation in human erythrocyte ghosts. Proc. Soc. Exp. Biol. Med. 143 : 565-567.

10. Kotsumata, Y., and J. Asai. 1972. Ultrastructural changes of erythrocyte ghosts having no connection with hydrolysis of ATP. Arch. Biochim. Biophys. 150: 330332.

11. Wins, P., and E. Schoffeniels. 1966. Studies on red-cell ghost ATPase systems: properties of a $\left(\mathrm{Mg}^{2+}+\mathrm{Ca}^{2+}\right)-$ dependent ATPase. Biochim. Biophys. Acta. 120: 341350 .

12. Schatzmann, H. J. 1970. Transmembrane calcium movements in resealed human red cells. In Calcium and Cellular Function. A. W. Cuthbert, editor. Macmillan \& Co. Ltd., London, England. 85-95.

13. Schatzmann, H. J., and F. F. Vincenzi. 1969. Calcium movements across the membrane of human red cells. J. Physiol. (Lond.). 201: 369-395.

14. Lee, K. S., and B. C. Shin. 1969. Studies on the active transport of calcium in human red cells. J. Gen. Physiol. 54 : 713-729.

15. Weiner, M. L., and K. S. Lee. 1972. Active calcium ion uptake by inside-out and right side-out vesicles of red blood cell membranes. J. Gen. Physiol. 59: 462-475.

16. Watson, E. L., F. F. Vincenzi, and P. W. Davis. 1971. $\mathrm{Ca}^{2+}$-activated membrane ATPase: selective inhibition by ruthenium red. Biochim. Biophys. Acta. 249: 606610.
17. Schrier, S. L., E. Giberman, D. Danon, and E. Katchalski. 1970. Studies on ATPase in sheared micro vesicles of human erythrocyte membranes. Biochim. Biophys. Acta. 196: 263-273.

18. Luft, J. H. 1971. Ruthenium red and violet. I. Chemistry, purification, methods of use for electron microscopy and mechanism of action. Anat. Rec. 171: 347-368.

19. Schrier, S. L. 1967. ATP synthesis in human erythrocyte membranes. Biochim. Biophys. Acta. 135: 591-598.

20. Bodemann, H., and H. Passow. 1972. Factors controlling the resealing of the membrane of human erythrocyte ghosts after hypotonic hemolysis. J. Membr. Biol. 8: $1-26$.

21. Schatzmann, H. J. 1973. Dependence on calcium concentration and stoichiometry of the calcium pump in human red cells. J. Physiol. (Lond.). 235: 551-569.

22. Bramley, T. A., and R. Coleman. 1972. Effects of inclusion of $\mathrm{Ca}^{2+}, \mathrm{Mg}^{2+}$, EDTA or EGTA during the preparation of erythrocyte ghosts by hypotonic haemolysis. Biochim. Biophys. Acta. 290: 219-228.

23. Fujii, T., T. Sato, and T. Hanzawa. 1973. Calcium and magnesium contents of mammalian erythrocyte membranes. Chem. Pharm. Bull. (Tokyo). 21: 171-175.

24. Harrison, D. G., and C. Long. 1968. The calcium content of human erythrocytes. J. Physiol. (Lond.). 199: 367-381.

25. Schrier, S. L. 1966. Organization of enzymes in human erythrocyte membranes. Am. J. Physiol. 210: 139-145.

26. Moore, C. L. 1971. Specific inhibition of mitochondrial $\mathrm{Ca}^{++}$transport by ruthenium red. Biochim. Biophys. Res. Commun. 42: 298-305.

27. Luft, J. H. 1971. Ruthenium red and violet. II. Fine structural localization in animal tissues. Anat. Rec. 171: 369-416.

28. Wins, P., and E. Schoffeniels. 1966. ATP ${ }^{+}$and $\mathrm{Ca}^{++}-$ linked contraction of red cell ghosts. Arch. Int. Physiol. Biochem. 74: 812-820.

29. Palek, J., W. A. Curby, and F. J. Lionetti. 1972. Size dependence of ghosts from stored erythrocytes on calcium and adenosine triphosphate. Blood. 40: 261-275.

30. Palek, J., G. Stewart, and F. J. Lionetti. 1974. The dependence of shape of human erythrocyte ghosts on calcium, magnesium and adenosine triphosphate. Blood. 44 : $583-597$.

31. Allen, J. E., and C. R. Valeri. 1974. Prostaglandins in hematology. Arch. Intern. Med. 133: 86-96.

32. Weed, R. I., P. L. LaCelle, and E. W. Merrill. 1969. Metabolic dependence on red cell deformability. J. Clin. Invest. 48: 795-809.

33. LaCelle, P. L. 1970. Alteration of membrane deformability in hemolytic anemias. Semin. Hematol. 7: 355371.

34. Triplett, R. B., J. M. Wingate, and K. L. Carraway. 1972. Calcium effects on erythrocyte membrane proteins. Biochem. Biophys. Res. Commun. 49: 1014-1020.

35. Wilson, L., J. Bryn, A. Ruby, and D. Mazia. 1970. Precipitation of proteins by vinblastine and calcium ions. Proc. Natl. Acad. Sci. U. S. A. 66: 807-814.

36. Kury, P. G., P. W. Ramwell, and H. M. McConnell. 1974. The effect of prostaglandins $E_{1}$ and $E_{2}$ on the human erythrocyte as monitored by spin labels. Biochem. Biophys. Res. Commun. 56: 478-483.

37. Poste, G., and A. C. Allison. 1973. Membrane fusion. Biochim. Biophys. Acta. 300: 421-465. 